\title{
Immunohistochemical characterization of neurons in the vestibular ganglion (Scarpa's ganglion) of the pig
}

\author{
A. Dudek, W. Sienkiewicz, J. Kaleczyc \\ Department of Animal Anatomy, Faculty of Veterinary Medicine, \\ University of Warmia and Mazury, Oczapowskiego 13, 10-719 Olsztyn, Poland
}

\begin{abstract}
The study was carried out on three 4-month old female pigs. All the animals were deeply anesthetized and transcardially perfused with $4 \%$ buffered paraformaldehyde ( $\mathrm{pH}$ 7.4). Vestibular ganglia (VG) were collected and processed for double-labelling immunofluorescence method. The preparations were examined under the Zeiss LSM 710 confocal microscope equipped with adequate filter blocks.

Neurons forming VG were round or oval in shape with a round nucleus in the center. The majority of them (58\%) were medium (M) $(31-50 \mu \mathrm{m}$ in diameter) while $28 \%$ and $14 \%$ were small (S) (up to $30 \mu \mathrm{m}$ in diameter) or large (L) (above $50 \mu \mathrm{m}$ in diameter) in size, respectively.

Double-labeling immunofluorescence revealed that VG neurons stained for CGRP (approx. $81 \%$; among them $70.5 \%, 26.2 \%$ and $3.3 \%$ were $\mathrm{M}, \mathrm{S}$ and L in size, respectively), VACHT (57\%; $63 \%$ M, 24\% S, 13\% L), Met-Enk (25\%; 60\% M, $12 \%$ S, $28 \%$ L), VIP (20\%; $88 \%$ M, 6\% S, L), NPY $(15 \% ; 67 \% \mathrm{M}, 20 \% \mathrm{~S}, 13 \% \mathrm{~L})$, GAL $(15 \% ; 74 \% \mathrm{M}, 21 \% \mathrm{~S}, 5 \% \mathrm{~L}), \mathrm{SP}(12 \% ; 69 \% \mathrm{M}, 25 \% \mathrm{~S}, 6 \% \mathrm{~L})$ and NOS-positive (12\%; 50\% S, 50\% M).

The most abundant populations of intraganglionic nerve fibers were those which stained for CGRP or Met-Enk, whereas only single SP- or NOS-positive nerve terminals were observed.
\end{abstract}

Key words: vestibular ganglion, Scarpa's ganglion, immunohistochemistry, pig

\section{Introduction}

Previously the vestibular ganglion (VG) called also the Scarpa's ganglion has been considered as consisting of only bipolar neurons. Their peripheral processes receive and conduct stimuli from hair cells, and the central processes transmit this information to neurons located within nuclei of the brain stem (Gray 1988). This textbook knowledge has been confirmed by studies utilizing tracing methods performed on rat and mice (Maklad and Fritzsch 1999, Maklad and Fritzsch 2002, Maklad et al. 2010), chicken (Cox and Peusner 1990), squirrel monkey and arctic ground squirrel (Carpenter and Cowie 1985).

The morphology of VG cells has been described in details in humans (Thurner et al. 1996) and in many laboratory animal species including the rat (Curthoys 1981, Ylikoski et al. 1993), guinea pig (Ballantyne and

Correspondence to: A. Dudek, e-mail: agnieszka.dudek@uwm.edu.pl 
Engstrom 1969, Curthoys 1981), gerbil (Perachio and Kevetter 1985), cat (Richter and Spoendlin 1981), rhesus monkey (Kitamura and Suzuki 1989). Recent studies have revealed the existence of the population of multipolar neurons within $\mathrm{VG}$ in the rat (Yamashita and Sekitani 1990), guinea pig (Ballantyne and Engstrom 1969), cat (Chat and Sans 1979) and humans (Ylikoski and Belal, Jr. 1981, Kitamura and Kimura 1983). The literature in the field contains only a few papers dealing with the immunohistochemical features of VG neurons from chick and rat embryos cultured nerve cells (Yamashita and Sekitani 1990, Yamashita et al. 1991) in adult mouse (Inafuku et al. 2000, Tritto et al. 2009), guinea pig (Yamashita et al. 1992), gerbil (Kevetter and Leonard 2002), chinchilla (Iurato et al. 1974), pigeon (Li et al. 2007) and in humans (Kanonier et al. 1996). These studies have revealed the presence of some different neurotransmitter substances within VG neurons.

The population of SP-positive neurons was described in rat and chick embryos cultured cells (Yamashita et al. 1991) in adult guinea pig (Usami et al. 1991, Jin 1992, Usami et al. 1993) and also in humans (Felix and Felix 1995, Felix et al. 1996). In the guinea pig, this population constituted $85 \%$ of VG neurons (Usami et al. 1993). Moreover, above 35\% of neurons within VG in guinea were NFP (neurofilament protein) - immunoreactive and some of them were also SP-positive (Usami et al. 1993). Surprisingly, no CGRP-immunoreactivity in VG neurons was found in humans (Popper et al. 2002a) and in the rat (Wackym et al. 1993) but only unmyelinated CGRP-immunoreactive nerve fibers passed among the primary afferent fibers through the VG to the epithelium of the vestibular end organs originating from CGRP-positive neurons located in vestibular nuclei in the brainstem (Chi et al. 2007).

Immunohistochemical studies have revealed the presence of the population of cholinergic neurons within VG in the rat (Yamashita and Sekitani 1990), chick embryo (Yamashita and Sekitani 1990, Yamashita et al. 1991) adult rat (Wicke et al. 1976), squirrel monkey (Baurle et al. 1999), chinchilla (Iurato et al. 1974) and humans (Popper et al. 2002a). The histochemical studies performed on rats (Wicke et al. 1976) have revealed the three types of cholinergic neurons: weakly, medium and strongly stained.

Also the presence of two isoforms (eNOS and nNOS) of nitric oxide synthase has been reported in vestibular ganglion cells of the mice (Hess et al. 1998) and guinea pig (Takumida and Anniko 1998) but no precise data regarding the number of the neurons have been provided. The large (49\%) population of NPY-immunoreactive nerve cells within VG has been found in the guinea pig (Lin et al. 2010).
In the rat, the presence of GAL-positive neuronal somata within VG and GAL-immunoreactive receptors on the hair cells have been observed, which indicates a interaction between vestibular hair cells and vestibular afferent neurons (Popper et al. 2007).

As judged from the above literature, the data regarding immunohistochemical features of VG neurons are very limited and have been obtained in birds, laboratory animals and humans, but there is no such information regarding large domestic animals, in this number also the pig. Therefore, this study was aimed at investigating the chemical coding of nerve structures in the porcine VG.

\section{Materials and Methods}

The study was carried out on three 4-month-old female pigs of the Polish Landrace breed, weighing 40-45 kg each. The animals were housed and treated in accordance with the rules approved by the local Ethics Commission (affiliated to the National Ethics Commission for Animal Experimentation, Polish Ministry of Science and Higher Education). All the animals were pre-treated with Propionylpromasine (Combelen, Bayer, Germany; $0.4 \mathrm{mg} / \mathrm{kg}$ of b.w. i.m.) $30 \mathrm{~min}$ before the main anesthetic, Pentobarbital (Vetbutal, Biowet, Poland; $25 \mathrm{mg} / \mathrm{kg}$ of b.w.), was given intravenously. Then, they were transcardially perfused with 0.51 of preperfusion solution containing $0.9 \%$ sodium chloride (Chemia, Gliwice, Poland), $2.5 \%$ polyvinylpyrolidone (Sigma, Deisenhofen, Germany), $0.5 \%$ procaine hydrochloride (Polfa, Warsaw, Poland), and 20000 IU of heparin (Heparinum; Polfa; added extempore), followed by $8-101$ of $4 \%$ ice-cold buffered paraformaldehyde ( $\mathrm{pH}$ 7.4), and VG were collected. The tissues collected were postfixed by immersion in the same fixative for $30 \mathrm{~min}$., rinsed with phosphate buffer $(\mathrm{pH}$ 7.4), and transferred to and stored in $18 \%$ buffered sucrose solution ( $\mathrm{pH} 7.4)$ until further processing.

The ganglia were cut into $12-\mu \mathrm{m}$-thick cryostat sections, which were processed for the double-immunofluorescence method on slide-mounted sections. The sections were washed for 3 times for $10 \mathrm{~min}$. in $\mathrm{PB}$, incubated $45 \mathrm{~min}$. in 10\% normal horse serum (NHS, Cappel, Warsaw, Poland) in PBS containing $0.25 \%$ Triton X-100 (Sigma, St. Louis, MO, USA), and then incubated overnight at room temperature (RT) with mixture of antibodies (Table 1) diluted in PB containing 1\% normal swine serum (NSS) and $0.25 \%$ Triton X-100. After incubation with primary antisera, the sections were washed for 3 times for 10 min. in $\mathrm{PB}$, and further incubated with secondary antisera for 1 hour at RT. After incubation, the sec- 
Table 1. Antisera used in the study.

\begin{tabular}{|c|c|c|c|c|c|c|}
\hline Antigen & Host & Type & Dilution & Cat. No. & Lot/Batch & Supplier \\
\hline \multicolumn{7}{|c|}{ Primary antisera } \\
\hline PGP-9,5 & mouse & polyclonal & $1: 2000$ & $13 \mathrm{C} 4$ & 21110903 & Biogenesis, UK \\
\hline CGRP & rabbit & polyclonal & $1: 2000$ & 11535 & $2659 \mathrm{~F}$ & Cappel \\
\hline SP & rat & monoclonal & $1 ; 150$ & $8450-0505$ & NC134 & ABD Serotec, UK \\
\hline VACHT & rabbit & polyclonal & $1: 5000$ & V5387 & 095K4751 & Sigma \\
\hline NOS & rabbit & polyclonal & $1: 2000$ & 11736 & 8648C & Cappel \\
\hline NPY & rabbit & polyclonal & $1: 400$ & NA1233 & Z07336 & Biomol \\
\hline GAL & rabbit & polyclonal & $1: 2000$ & RIN 7153 & $990921-2$ & Peninsula Lab. \\
\hline VIP & mouse & monoclona & $1: 500$ & MaVIP & 91278 & East Acres Biologicals \\
\hline Met-ENK & rabbit & polyclonal & $1: 500$ & RPN 1562 & 11461 & Amersham \\
\hline \multicolumn{7}{|c|}{ Secondary antisera } \\
\hline \multicolumn{2}{|c|}{ Host } & \multicolumn{2}{|c|}{ Fluorochrom } & Dilution & Code & Supplier \\
\hline \multicolumn{2}{|c|}{ Goat-anti-mouse $\operatorname{IgG}(\mathrm{H}+\mathrm{L})$} & \multicolumn{2}{|c|}{ Alexa Flour 488} & $1: 500$ & A11001 & Invitrogen \\
\hline \multirow{2}{*}{\multicolumn{2}{|c|}{ Goat-anti-rabbit IgG $(\mathrm{H}+\mathrm{L})$}} & \multicolumn{2}{|c|}{ Alexa Flour 568} & $1: 500$ & A11011 & Invitrogen \\
\hline & & \multicolumn{2}{|c|}{ Alexa Flour 546} & $1: 500$ & A11081 & Invitrogen \\
\hline
\end{tabular}

tions were washed for 3 times for $10 \mathrm{~min}$. in $\mathrm{PB}$ and cover slipped with buffered glycerol. Control of specificity of staining was performed by pre-absorption of a diluted antiserum with $20 \mathrm{ng} / \mathrm{ml}$ of an appropriate antigen (besides VACHT), which abolished the specific immunoreaction completely. In addition, experiments were carried out in which the primary antiserum was replaced by non-immune serum, or by PBS, to verify the specificity of particular immunoreactions. Preparations were studied, photographed and neurones were measured with a confocal microscope Zeiss LSM 700.

Counting of neurons: to determinate percentages of particular neuronal populations, at least 300 of neuronal profiles investigated for each combination of antisera were counted. The sections were collected from different, representative regions of the ganglion (from they upper, middle and lower one-third). To avoid double-counting of the same neurons, appropriate distance (minimum 6 sections $=70 \mu \mathrm{m}$ ) between the sections was maintained. The number of immunolabelled profiles was calculated as a percentage of immunoreactive neurons in regard to all (PGP 9.5-positive) perikarya counted. The data obtained were statistically analyzed. All the results are expressed as means \pm SEM. Statistical analysis was carried out in columns using GraphPad Prism v. 2.0 computer program (GraphPad Software Inc.).

\section{Results}

Neurons forming the VG were round or oval in shape with a round or oval nucleus located in the cell center. Over half of them $58 \%(58.33 \pm 2.0)$ were medium sized $(31-50 \mu \mathrm{m}), 28 \%(27.67 \pm 2.6)$ were small
$(20-30 \mu \mathrm{m})$ and $14 \%(13.67 \pm 2.4)$ were above the 50 $\mu \mathrm{m}$ in diameter (large neurons) (Diagram 1).

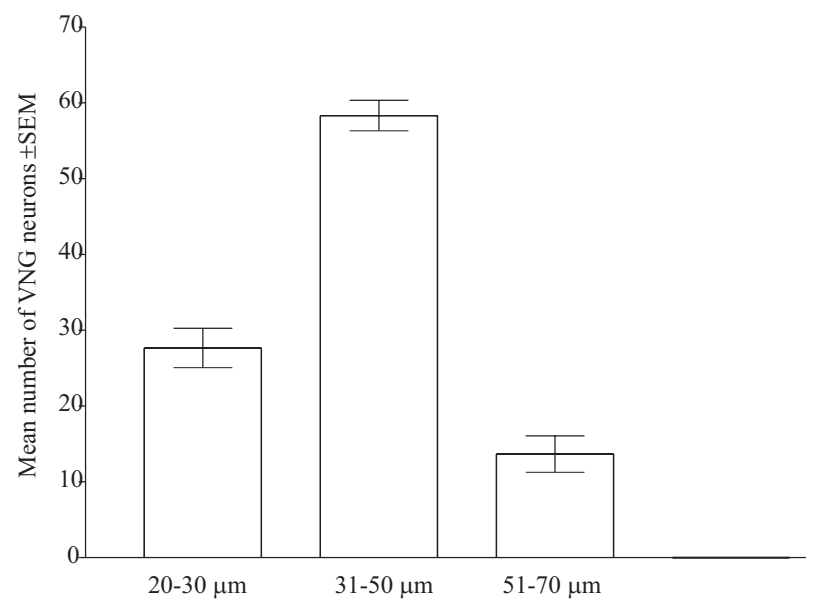

Diagram 1. Mean number of different size neurons within the VG.

Double labeling immunocytochemistry revealed that all VG neurons contained immunoreactivity to PGP 9.5. Approximately $81 \%$ of them were CGRP-immunoreactive (Fig. 1) (Diagram 2). Moreover, among CGRP-immunoreactive (Fig. 1) neurons $70.5 \%$ were medium, $26.2 \%$ were small and $3.3 \%$ were large sized. The investigation revealed also numerous intraganglionic CGRP-positive nerve fibers. SP (Fig. 2) or nNOS (Fig. 4) were expressed by $12 \%$ of VG perikarya. SP-positive neurons represented three size categories. Sixty nine percent of them were medium sized, $25 \%$ belonged to the population of small perikarya, and $6 \%$ were large neurons. nNOS-positive nerve cell bodies represented only two size categories, namely half of them belonged to the 


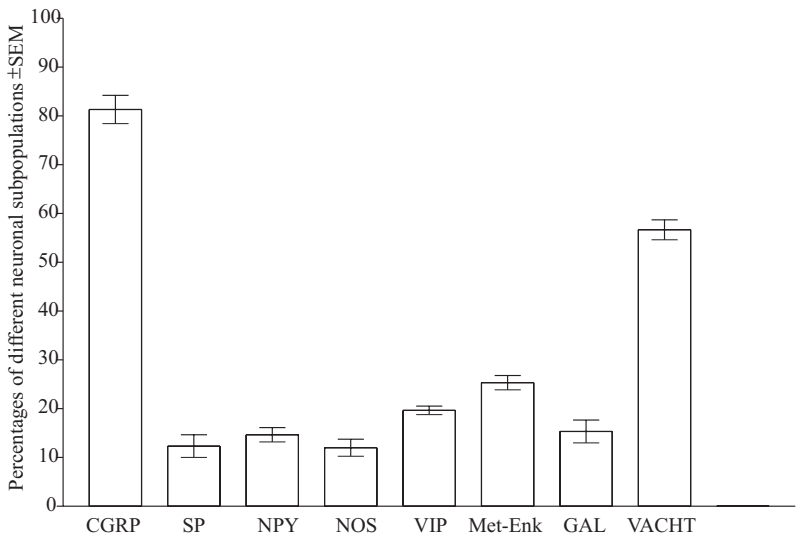

Diagram 2. Percentages of different neuronal subpopulations within the VG of the pig.

population of small neurons and the remaining cells were medium in size. Only solitary SP- and NOS-immunoreactive intraganglionic nerve fibers were observed. Approximately $57 \%$ of neurons were cholinergic in nature (VACHT-IR). The population of cholinergic nerve cell bodies (Fig. 3) consisted of $63 \%, 24 \%$ and $13 \%$ medium, small and large in size neurons, respectively. Intraganglionic nerve fibers immunoreactive to VACHT were only single. NPY-immunoreactivity (Fig. 5) was present in $15 \%$ of all VG neurons. It was found that $67 \%$ of NPY+ neurons were of medium size, $20 \%$ belonged to the subset of small perikarya, and $13 \%$ represented large nerve cell bodies. GAL-immunoreactivity (Fig. 6) was found in $15 \%$ of all VG neurons. Among galaninergic neurons, $74 \%$ were medium in size, $21 \%$ represented subpopulation of small neurons, whereas only $5 \%$ belonged to the class of large nerve cells. VIP-immunoreactivity (Fig. 7) was present in $20 \%$ of all VG neurons, among them $88 \%$ were medium in size, $6 \%$ were small and $6 \%$ represented large neurons. Met-Enk-immunoreactivity (Fig. 8) was expressed by approx. $25 \%$ of all the neurons and numerous intraganglionic Met-Enk-immnoreactive nerve fibers were found. Among all Met-Enk-positive perikarya $60 \%$ were medium size, $12 \%$ were small and $28 \%$ were large size neurons.

\section{Discussion}

The present study has revealed that vast majority of VG neurons (82\%) displayed immunoreactivity for CGRP. This observation differs from results obtained in the rat (Wackym et al. 1993) and humans (Popper et al. 2002a). In these species VG contain no CGRP-positive neurons, but numerous unmyelinated CGRP-immunoreactive nerve fibers have been observed. The authors of these studies have suggested that these fibers only pass among the primary afferent fibers within the ganglion to reach the target structures - subepithelial regions of vestibular endorgans. All the CGRP-positive fibers were also CHAT-immunoreactive and were classified as efferent fibers originating from the vestibular nuclei. In our study only single cholinergic intraganglionic nerve fibers were found while CGRP-immunoreactive nerve terminals were most abundant. It was also found that only $12 \%$ of VG neurons were SP-positive. Our findings do not corroborate previous data regarding the presence of SP-immunoreactive neurons in a population of VG neurons. It has been reported that over $85 \%$ of VG neurons in the guinea pig were SP-positive (Usami et al. 1993), thus we can observe an inverse relation regarding the population of CGRP- and SP-immunoreactive neurons within porcine and other species VG. Our study has revealed the large population of CGRP-positive neurons within VG whereas in other species no CGRP-immunoreactive cells were found (Popper et al. 2002a). These species dependent differences could be explained by the different roles played by both neurotransmitters in the pig and in other species. Probably in the pig CGRP plays a role of a major neurotransmitter whereas SP has only a supporting role in sensory transmission.

Another large (nearly 57\%) subpopulation shown in the present investigation are VACHT-immunoreactive neurons. Cholinergic neurons were previously described in VG in some animal species and also in humans (Iurato et al. 1974, Wicke et al. 1976, Popper et al. 2002a). Unfortunately, no precise data regarding the number of cholinergic neurons are pro-

Fig. 1. Numerous CGRP-positive neurons (labelled with Alexa Fluor ${ }^{\circledR}$ 568) within the porcine vestibular ganglion. Green channel for PGP-9.5 labelled with Alexa Fluor ${ }^{\circledR} 488$ was disabled (also in case of Figs. 2-8) for better visualization of the red channel. Arrows show single CGRP-negative nerve cells. Scale bar $=100 \mu \mathrm{m}$; Fig. 2. Moderate number of SP-positive neurons (arrows; labelled with Alexa Fluor ${ }^{\circledR}$ 546) within the porcine vestibular ganglion. Scale bar $=200 \mu \mathrm{m}$; Fig. 3. Numerous VACHT-positive neurons (arrows; labelled with Alexa Fluor ${ }^{\circledR} 568$ ) within the porcine vestibular ganglion. Note the presence of product of immunoreaction in the cytoplasm of perikarya in form of granules. Scale bar $=100 \mu \mathrm{m}$; Fig. 4 . Moderate number of NOS-positive neurons (arrow; labelled with Alexa Fluor ${ }^{\circledR} 568$ ) within the porcine vestibular ganglion. Scale bar $=200 \mu \mathrm{m}$; Fig. 5. Moderate number of NPY-positive neurons (arrows; labelled with Alexa Fluor ${ }^{\circledast}$ 568) within the porcine vestibular ganglion. Scale bar $=100 \mu \mathrm{m}$; Fig. 6. Moderate number of GAL-positive neurons (arrows; labelled with Alexa Fluor ${ }^{\circledR}$ 568) within the porcine vestibular ganglion. Scale bar $=200 \mu \mathrm{m}$. 


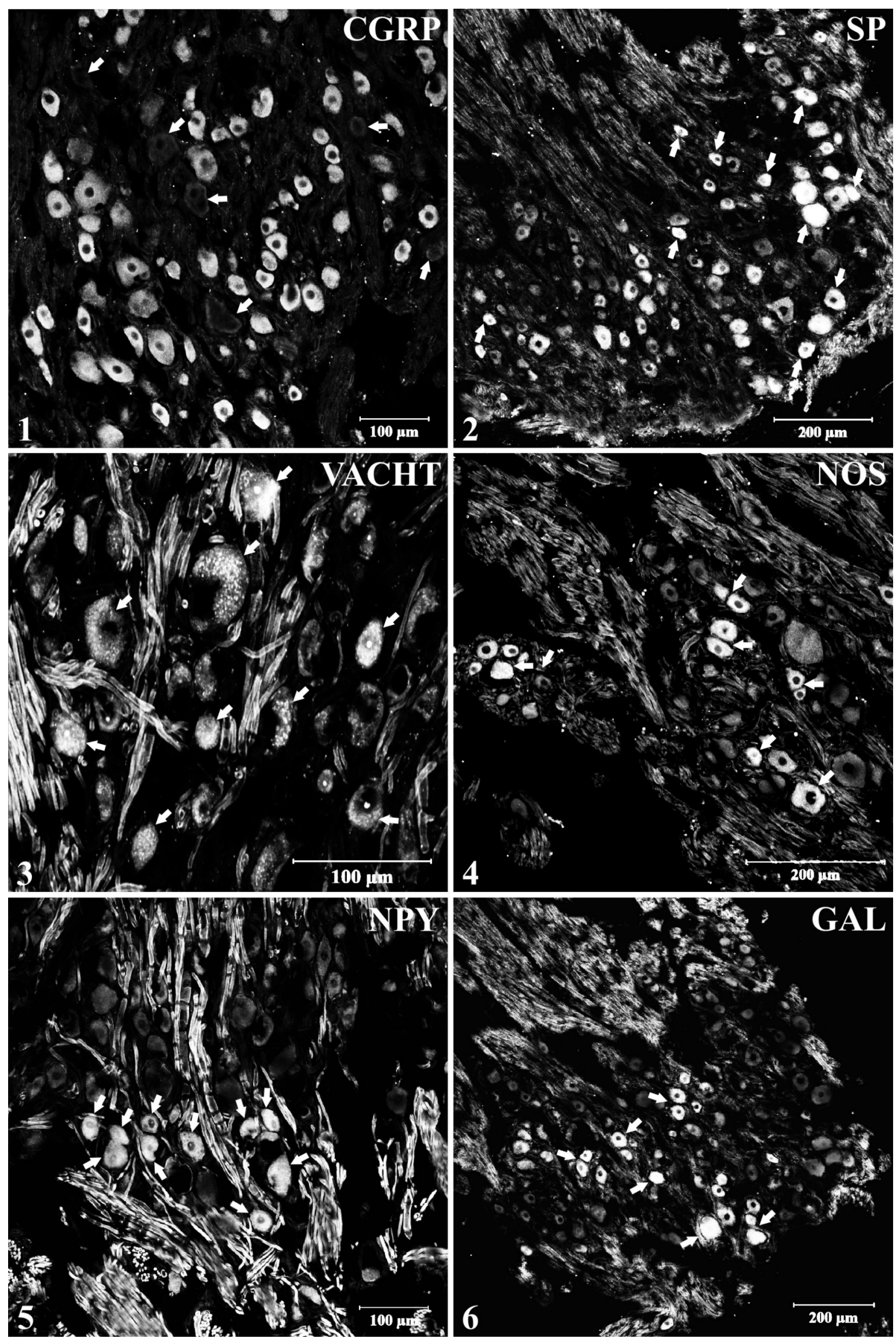



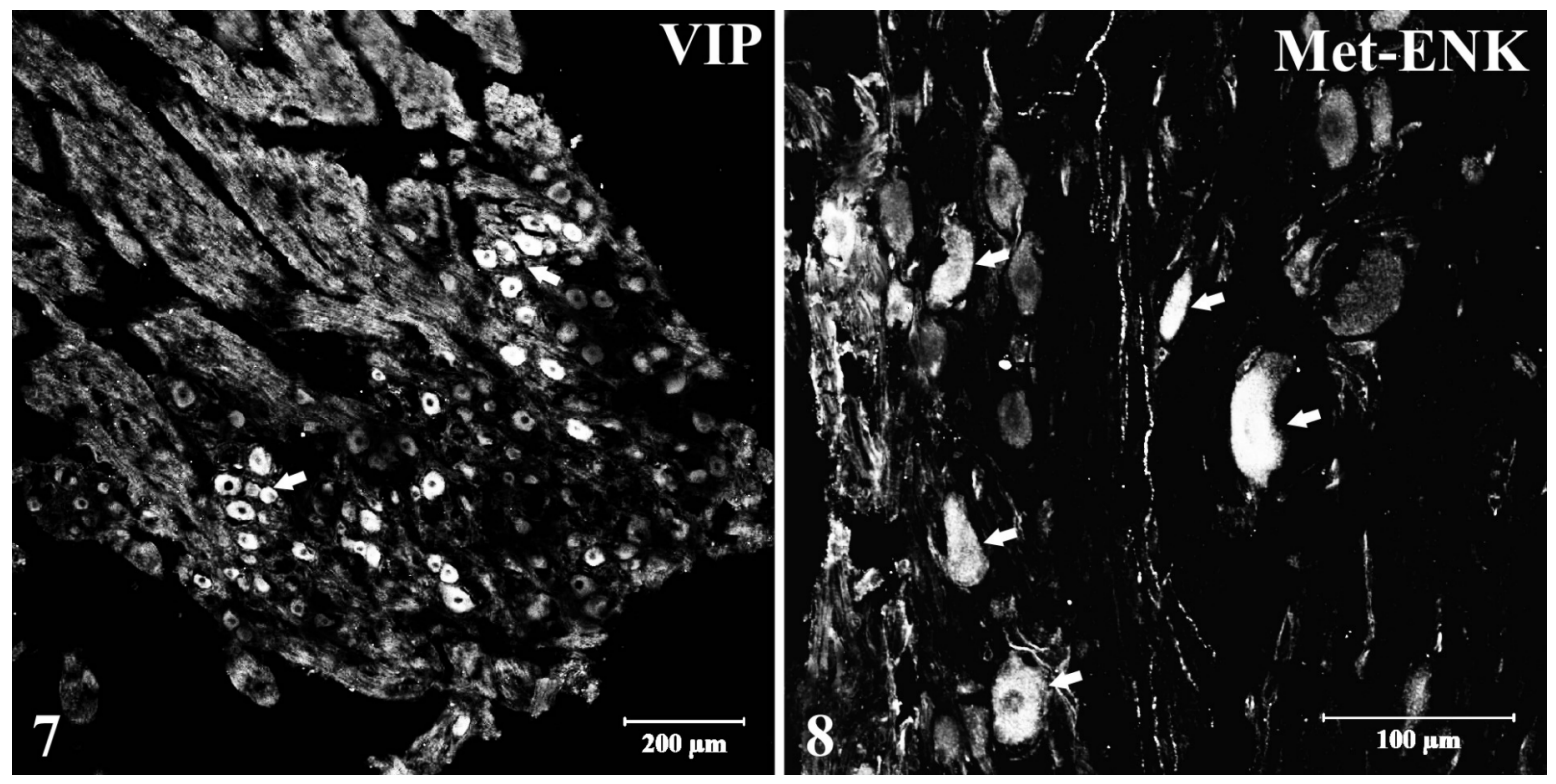

Fig. 7. Moderate number of VIP-positive neurons (labelled with Alexa Fluor ${ }^{\circledR} 568$ ) within the porcine vestibular ganglion. Arrows show groups of the immunoreactive neurons. Scale bar $=200 \mu \mathrm{m}$; Fig. 8. Moderate number of Met-ENK-positive neurons (arrows; labelled with Alexa Fluor ${ }^{\circledR}$ 568) within the porcine vestibular ganglion. Note the presence of numerous immunoreactive nerve fibers. Scale bar $=100 \mu \mathrm{m}$.

vided in these reports, but the authors of the paper dealing with the role of CHAT in primary afferent neurons of the vestibular system have suggested that acetylcholine may be involved in modulation or co-transmission in conducting of static stimuli (Baurle et al. 1999). It was also mentioned in a previous paper (Tata et al. 2004) that VACHT can play an important role in the communication between neurons within sensory ganglia.

The presence of two isoforms of nitric oxide synthase: eNOS and nNOS in neurons and nerve fibers within VG has been previously described in the mouse (Hess et al. 1998) and guinea pig (Takumida and Anniko 1998) but there is no information regarding a number of these cells. However, the present study has revealed that more than $12 \%$ of VG neurons contain nNOS-immunoreactivity and also single nNOS-positive intraganglionic nerve fibers were found. It is known that NO significantly contributes to the basal discharge and response of afferent fibers to mechanical stimuli of the vestibular afferent fibers and probably participates in the sensory coding and adaptative changes of the vestibular input in normal and pathological conditions (Flores et al. 1996, Flores et al. 2001). Thus it can be assumed that in the pig NOS-positive neurons play a role in conducting stimuli from the vestibular end organs.

In primary afferents neuropeptide $\mathrm{Y}$ plays a modulatory role in processing nociceptive information. Studies on cultured sensory neurons from mouse DRG showed inhibitory function of NPY in antero- grade and retrograde neuronal transport (Hiruma et al. 2002). An increase of NPY-immunoreactivity within DRG was found after peripheral nerve injuries of primary afferents in the rat (Wakisaka et al. 1992). Studies dealing with NPY and SP expression level in the guinea pig have revealed a decrease in the number of NPY-immunoreactive neurons in VG after gentamycin treatment (Lin et al. 2010). Until now, the presence of the NPY-immunoreactive neurons within VG in normal condition was reported only in the guinea pig (Lin et al. 2010). Over a half of all guinea pig VG neurons expressed NPY while our study has revealed over $15 \%$ of NPY-positive neurons located in the porcine vestibular ganglion. Our findings differ from those described above, but this discrepancy is probably result of interspecies differences.

The presence of $\mu$ and $\delta$ opioid receptors in VG neurons was described by (Popper et al. 2002b). The $\mu$ opioid receptors play a regulatory role in the activity of vestibular afferent neurons, mediating an excitatory, postsynaptic modulatory input to these nerve cells (Vega and Soto 2003). In the present study, more than $25 \%$ of neurons within VG displayed immunoreactivity to Met-Enk and also very numerous intraganglionic nerve fibers expressing this peptide was observed. The population of neurons containing Met-Enk m-RNA was also reported in the nodosal ganglion of the rat (Czyzyk-Krzeska et al. 1991).

The available literature contains only a few reports regarding the presence of GAL-positive neurons in sensory ganglia including mammalian trigeminal 
ganglion (Lazarov 2002), dorsal root ganglia (Ch'ng et al. 1985, Wiesenfeld-Hallin and Xu 1998, Landry et al. 2003), porcine nodose ganglion (Philippe et al. 1990) and also in rat nodosal and petrosal ganglion (Calingasan and Ritter 1992, Ichikawa and Helke 1993, Zhuo et al. 1997). Until now, no evidence for the presence of galaninergic neurons within vestibular ganglion has been provided. The present study has revealed that over $20 \%$ of all VG neurons expressed GAL. It seems to be possible that GAL in porcine VG neurons has a similar role to that mentioned in some previous papers, suggesting that galaninergic DRG neurons in the rat and humans play a role in processing of pain information (Zhang et al. 1998, Landry et al. 2003).

In the pig, over $20 \%$ of all VG neurons expressed vasoactive intestinal peptide and this is the first paper reporting VIP-immunoreactivity within VG. Previously, VIP-positive sensory neurons were described in horse and porcine dorsal root ganglia (Merighi et al. 1990) and also some VIP-immunoreactive neurons were found in the nodose and petrosal ganglion of the rat (Helke and Hill 1988, Helke and Rabchevsky 1991, Zhuo et al. 1997).

In conclusion, the present study has revealed the chemical coding of nerve structures located in the porcine vestibular ganglion by immunohistochemistry. It should be mentioned that this is the first report dealing with immunohistochemical properties of Scarpa's ganglion nerve structures in large domestic animal species. The results obtained suggest the existence of profound differences in the chemical coding of vestibular ganglion neurons between the pig and small laboratory animals, and humans.

\section{References}

Ballantyne J, Engstrom H (1969) Morphology of the vestibular ganglion cells. J Laryngol Otol 83: 19-42.

Baurle J, Bruning G, Schemann M, Nishiike S, Guldin WO (1999) Co-localization of glutamate, choline acetyltransferase and glycine in the mammalian vestibular ganglion and periphery. Neuroreport 10: 3517-3521.

Calingasan NY, Ritter S (1992) Presence of galanin in rat vagal sensory neurons: evidence from immunohistochemistry and in situ hybridization. J Auton Nerv Syst 40: $229-238$

Carpenter MB, Cowie RJ (1985) Transneuronal transport in the vestibular and auditory systems of the squirrel monkey and the arctic ground squirrel. I. Vestibular system. Brain Res 358: 249-263.

Chat M, Sans A (1979) Multipolar neurons in the cat vestibular ganglion. Neuroscience 4: 651-657.

Ch'ng JL, Christofides ND, Anand P, Gibson SJ, Allen YS, Su HC, Tatemoto K, Morrison JF, Polak JM, Bloom SR
(1985) Distribution of galanin immunoreactivity in the central nervous system and the responses of galanin-containing neuronal pathways to injury. Neuroscience 16: 343-354.

Chi FL, Jiao Y, Liu HJ, Wang J, Shi Y, Barr JJ (2007) Retrograde neuron tracing with microspheres reveals projection of CGRP-immunolabeled vestibular afferent neurons to the vestibular efferent nucleus in the brainstem of rats. Neuroendocrinology 85: 131-138.

Cox RG, Peusner KD (1990) Horseradish peroxidase labeling of the central pathways in the medulla of the ampullary nerves in the chicken, Gallus gallus. J Comp Neurol 297: 564-581.

Curthoys IS (1981) Scarpa's ganglion in the rat and guinea pig. Acta Otolaryngol 92: 107-113.

Czyzyk-Krzeska MF, Bayliss DA, Lawson EE, Millhorn DE (1991) Expression of messenger RNAs for peptides and tyrosine hydroxylase in primary sensory neurons that innervate arterial baroreceptors and chemoreceptors. Neurosci Lett 129: 98-102.

Felix D, Felix H (1995) Intracellular study of substance P in human Scarpa's ganglion cells. ORL J Otorhinolaryngol Relat Spec 57: 15-17.

Felix H, Schickinger B, Felix D (1996) Immunohistochemical and electrophysiological demonstration of substance $\mathrm{P}$ in human vestibular ganglion cells. Acta Otolaryngol 116: 273-276.

Flores A, Leon-Olea M, Vega R, Soto E (1996) Histochemistry and role of nitric oxide synthase in the amphibian (Ambystoma tigrinum) inner ear. Neurosci Lett 205: 131-134.

Flores A, Soto E, Vega R (2001) Nitric oxide in the afferent synaptic transmission of the axolotl vestibular system. Neuroscience 103: 457-464.

Gray H (1988) Gray's Anatomy: The Classic Collector's Edition. Random House Value Publishing, Incorporated, New York, NY, USA

Helke CJ, Hill KM (1988) Immunohistochemical study of neuropeptides in vagal and glossopharyngeal afferent neurons in the rat. Neuroscience 26: 539-551.

Helke CJ, Rabchevsky A (1991) Axotomy alters putative neurotransmitters in visceral sensory neurons of the nodose and petrosal ganglia. Brain Res 551: 44-51.

Hess A, Bloch W, Arnhold S, Andressen C, Stennert E, Addicks K, Michel O (1998) Nitric oxide synthase in the vestibulocochlear system of mice. Brain Res 813: 97-102.

Hiruma H, Saito A, Kusakabe T, Takenaka T, Kawakami $\mathrm{T}$ (2002) Neuropeptide $\mathrm{Y}$ inhibits axonal transport of particles in neurites of cultured adult mouse dorsal root ganglion cells. J Physiol 543: 85-97.

Ichikawa H, Helke CJ (1993) Distribution, origin and plasticity of galanin-immunoreactivity in the rat carotid body. Neuroscience 52: 757-767.

Inafuku $\mathrm{S}, \mathrm{Wu} \mathrm{M}$, Kimura M, Nakayama $\mathrm{M}$, Nakano $\mathrm{T}$, Ishigami H (2000) Immunohistochemical demonstration of inducible nitric oxide and nuclear factor-kappa B with reference to age-related changes in the mouse spiral and vestibular ganglion. Okajimas Folia Anat Jpn 77: 125-131.

Iurato S, Luciano L, Franke K, Pannese E, Reale E (1974) Histochemical localization of acetylcholinesterase activity in the cochlear and vestibular ganglion cells. Acta Otolaryngol 78: 28-35. 
Jin H (1992) [Immunohistochemical studies on the guinea pig's vestibular ganglion cell-with reference to the distribution of substance $\mathrm{P}$ and neurofilament]. Nippon Jibiinkoka Gakkai Kaiho 95: 391-399.

Kanonier G, Thurner KH, Scholtz A, Schrott-Fischer A (1996) Immunohistochemical Investigation on the $\mathrm{Hu}$ man Vestibular Ganglion. Otolaryngology - Head and Neck Surgery 115: 146.

Kevetter GA, Leonard RB (2002) Molecular probes of the vestibular nerve. II. Characterization of neurons in Scarpa's ganglion to determine separate populations within the nerve. Brain Res 928: 18-29.

Kitamura K, Kimura RS (1983) Synaptic structures of the human vestibular ganglion. Adv Otorhinolaryngol 31: 118-134

Kitamura K, Suzuki M (1989) Ultrastructural findings of the macaque monkey vestibular ganglion cells. Acta Otolaryngol (Suppl) 468: 23-29.

Landry M, Aman K, Dostrovsky J, Lozano AM, Carlstedt T, Spenger C, Josephson A, Wiesenfeld-Hallin Z, Hokfelt $\mathrm{T}$ (2003) Galanin expression in adult human dorsal root ganglion neurons: initial observations. Neuroscience 117: 795-809.

Lazarov NE (2002) Comparative analysis of the chemical neuroanatomy of the mammalian trigeminal ganglion and mesencephalic trigeminal nucleus. Prog Neurobiol. 66: 19-59.

Li GQ, Kevetter GA, Leonard RB, Prusak DJ, Wood TG, Correia MJ (2007) Muscarinic acetylcholine receptor subtype expression in avian vestibular hair cells, nerve terminals and ganglion cells. Neuroscience 146: 384-402.

Lin CT, Young YH, Cheng PW, Lue JH (2010) Effects of gentamicin on guinea pig vestibular ganglion function and on substance $\mathrm{P}$ and neuropeptide Y. J Chem Neuroanat 40: 286-292.

Maklad A, Fritzsch B (1999) Incomplete segregation of endorgan-specific vestibular ganglion cells in mice and rats. J Vestib Res 9: 387-399.

Maklad A, Fritzsch B (2002) The developmental segregation of posterior crista and saccular vestibular fibers in mice: a carbocyanine tracer study using confocal microscopy. Brain Res Dev Brain Res 135: 1-17.

Maklad A, Kamel S, Wong E, Fritzsch B (2010) Development and organization of polarity-specific segregation of primary vestibular afferent fibers in mice. Cell Tissue Res 340: 303-321.

Merighi A, Kar S, Gibson SJ, Ghidella S, Gobetto A, Peirone SM, Polak JM (1990) The immunocytochemical distribution of seven peptides in the spinal cord and dorsal root ganglia of horse and pig. Anat Embryol (Berl) 181: 271-280.

Perachio AA, Kevetter GA (1985) Morphological characteristics of neurons in the inferior and superior divisions of scarpa's ganglion in the gerbil. Prog Clin Biol Res 176: 263-277.

Philippe C, Cuber JC, Bosshard A, Rampin O, Laplace JP, Chayvialle JA (1990) Galanin in porcine vagal sensory nerves: immunohistochemical and immunochemical study. Peptides 11: 989-993.

Popper P, Ishiyama A, Lopez I, Wackym PA (2002a) Calcitonin gene-related Peptide and choline acetyltran- sferase colocalization in the human vestibular periphery. Audiol Neurootol 7: 298-302.

Popper P, Siebenreich W, Erbe Ch, Samuels T, Lerch-Gaggl A, Wackym PA (2007) Neuropeptides and Neuropeptide Receptors in the Rat Vestibular Periphery. http: //www. aro org/archives/2007/2007-620 html

Popper P, Wackym PA, Siebenreich W, Cristobal R (2002b) Distribution of Opioid Receptors in the Vestibular Periphery. http://www.aro.org/abstracts/ARO\%20Abs-Search\%202 pdf

Richter E, Spoendlin H (1981) Scarpa's ganglion in the cat. Acta Otolaryngol 92: 423-431.

Takumida M, Anniko M (1998) Localization of nitric oxide synthase isoforms (NOS I, II and III) in the vestibular end organs of the guinea pig. ORL J Otorhinolaryngol Relat Spec 60: 67-72.

Tata AM, De Stefano ME, Srubek TG, Vilaro MT, Levey AI, Biagioni S (2004) Subpopulations of rat dorsal root ganglion neurons express active vesicular acetylcholine transporter. J Neurosci Res 75: 194-202.

Thurner KH, Kanonier G, Wimmer M, Helbock C, Ulmer $\mathrm{H}$, Schrott-Fischer A (1996) Morphometric and ultrastructural findings on human vestibular ganglion cells. ORL J Otorhinolaryngol Relat Spec 58: 213-218.

Tritto S, Botta L, Zampini V, Zucca G, Valli P, Masetto $S$ (2009) Calyx and dimorphic neurons of mouse Scarpa's ganglion express histamine $\mathrm{H} 3$ receptors. BMC Neurosci 10: 70 .

Usami S, Hozawa J, Shinkawa H, Tazawa M, Jin H, Matsubara A, Fujita S, Ylikoski J (1993) Immunocytochemical localization of substance $\mathrm{P}$ and neurofilament proteins in the guinea pig vestibular ganglion. Acta Otolaryngol (Suppl) 503: 127-131.

Usami S, Hozawa J, Tazawa M, Jin H, Matsubara A, Fujita S (1991) Localization of substance P-like immunoreactivity in guinea pig vestibular endorgans and the vestibular ganglion. Brain Res 555: 153-158.

Vega R, Soto E (2003) Opioid receptors mediate a postsynaptic facilitation and a presynaptic inhibition at the afferent synapse of axolotl vestibular hair cells. Neuroscience 118: 75-85.

Wackym PA, Popper P, Micevych PE (1993) Distribution of calcitonin gene-related peptide mRNA and immunoreactivity in the rat central and peripheral vestibular system. Acta Otolaryngol 113: 601-608.

Wakisaka S, Kajander KC, Bennett GJ (1992) Effects of peripheral nerve injuries and tissue inflammation on the levels of neuropeptide Y-like immunoreactivity in rat primary afferent neurons. Brain Res 598: 349$-352$.

Wicke W, Firbas W, Rameis R, Sinzinger H (1976) On the acetylcholinesterase activity in the vestibular ganglion of the rat. Acta Morphol Neerl Scand 14: 31-38.

Wiesenfeld-Hallin Z, Xu XJ (1998) Galanin in somatosensory function. Ann N Y Acad Sci 863: 383-389.

Yamashita H, Bagger-Sjoback D, Sekitani T (1992) Distribution of tyrosine hydroxylase-like immunofluorescence in guinea pig vestibular ganglia and sensory areas. Auris Nasus Larynx 19: 63-68.

Yamashita H, Sekitani T (1990) The demonstration of choline acetyltransferase activity in cultured vestibular gan- 
glion cells from the fetal rat. Eur Arch Otorhinolaryngol 247: 229-231.

Yamashita H, Sekitani T, Okinaka Y, Inokuma T, Shimogori H, Moriya K, Hara H (1991) Cell culture study of the vestibular ganglion cells. Morphology and immunohistochemical activity. Acta Otolaryngol Suppl 481: 153-157.

Ylikoski J, Belal A, Jr. (1981) Human vestibular nerve morphology and labyrinthectomy. Am J Otolaryngol 2: 81-93.

Ylikoski J, Pirvola U, Happola O (1993) Characterization of the vestibular and spiral ganglion cell somata of the rat by distribution of neurofilament proteins. Acta Otolaryngol (Suppl) 503: 121-126.

Zhang X, Xu ZO, Shi TJ, Landry M, Holmberg K, Ju G, Tong YG, Bao L, Cheng XP, Wiesenfeld-Hallin Z, Lozano A, Dostrovsky J, Hokfelt T (1998) Regulation of expression of galanin and galanin receptors in dorsal root ganglia and spinal cord after axotomy and inflammation. Ann N Y Acad Sci 863: 402-413.

Zhuo H, Ichikawa H, Helke CJ (1997) Neurochemistry of the nodose ganglion. Prog Neurobiol 52: 79-107. 